\title{
Zingiber officinale (Ginger) Extract has No Effect on Kiss1 Gene Expression in the Testis and Blood but May Cause Inflammation-induced Morphological Sperm Disruptions in Wistar Rats
}

\author{
Izuchukwu Azuka Okafor ${ }^{1,2,3 *}$, Uchenna Somtochukwu Nnamah ${ }^{4}$, \\ Johnson Okwudili Nweke ${ }^{5}$, Jude Amechi Nnaka ${ }^{1}$, Selasie \\ Ahiatrogah ${ }^{2,3}$ and Uche Valentine Okeke ${ }^{6}$ \\ ${ }^{1}$ Department of Anatomy, Faculty of Basic Medical Sciences, College of Health \\ Sciences, Nnamdi Azikiwe University, Nnewi, Nigeria \\ ${ }^{2}$ Department of Obstetrics and Gynaecology, College of Medicine, University of \\ Ibadan, Ibadan, Nigeria \\ ${ }^{3}$ Pan African University of Life and Earth Science Institute (Including Health and \\ Agriculture), PAULESI, University of Ibadan, Ibadan, Nigeria \\ ${ }^{4}$ Hematology Department, Babcock University Teaching Hospital, Ilisan Remo, Ogun \\ State, Nigeria \\ ${ }^{5}$ Diagnostic Laboratory Unit, Medical Centre, Michael Okpara University of \\ Agriculture, Umudike, Abia State, Nigeria \\ ${ }^{6}$ Morbid Anatomy Department, Alex Ekwueme Federal University Teaching Hospital \\ Abakaliki, Ebonyi State, Nigeria \\ *Corresponding Author: Izuchukwu Azuka Okafor, Department of Anatomy, \\ Faculty of Basic Medical Sciences, College of Health Sciences, Nnamdi Azikiwe \\ University, Nnewi, Nigeria.
}

\author{
Received: September 23, 2020 \\ Published: November 18, 2020
}

(C) All rights are reserved by Izuchukwu Azuka

Okafor., et al.

\section{Abstract}

Background: Zingiber officinale is used extensively both as a culinary spice and herbal medicine for the treatment of different ailments.

Aim: This study investigated the role of ginger in the Kiss1 gene expression in the testis of Wistar rats.

Methods: Fifteen (15) rats with an average weight of $104 \mathrm{~g}$ were randomly divided into three (3) groups (A-C). Group A was given no treatment and served as the normal control group. Groups B and C received oral administration of $200 \mathrm{mg} / \mathrm{kg}$ and $400 \mathrm{mg} / \mathrm{kg}$ of methanolic extract of Zingiber officinale (MEZO) respectively. The extract was administered once a day for 21 days.

Results: There was no significant difference in the testicular oxidative status, LH, FSH, TT, sperm motility, sperm count, and sperm morphology across all experimental groups $(\mathrm{p}<0.05)$ except for group $\mathrm{C}$ where a significant decrease in sperm morphology was observed compared to the control $(p=0.007)$. Some vascular congestions with visible aggregates of inflammatory red cells were also observed in group $\mathrm{C}$ testes. The relative intensity of Kiss1 gene expression observed in the testis is significantly higher than that in the blood at $200 \mathrm{mg} / \mathrm{kg}$ of MEZO (CI: $-1.39-(-0.05), \mathrm{p}=0.045)$ with a significant negative correlation between the sperm count and the relative intensity of KISS1 gene expression in the blood $(r=-.882, p=0.20)$.

Conclusion: MEZO does not affect the Kiss1 gene expression levels in the testis and blood of Wistar rats but shows the potential of causing sperm morphological disruptions due to testicular inflammatory response at a high dose.

Keywords: Zingiber officinale; Sperm Count; Sperm Morphology; Sperm Motility; Kiss1; Kisspeptin; Ginger; Gene Expression; Hormones; Testis; Histology; Oxidative Markers

Citation: Izuchukwu Azuka Okafor., et al. "Zingiber officinale (Ginger) Extract has No Effect on Kiss1 Gene Expression in the Testis and Blood but May Cause Inflammation-induced Morphological Sperm Disruptions in Wistar Rats”. Acta Scientific Medical Sciences 4.12 (2020): 17-25. 
Zingiber officinale (Ginger) Extract has No Effect on Kiss1 Gene Expression in the Testis and Blood but May Cause Inflammation-induced Morphological Sperm Disruptions in Wistar Rats

\section{Introduction}

Ginger (Zingiber officinale) is an underground rhizome used globally as a herbal supplement and culinary spice (White, 2007). It has been extensively used in traditional medicine as a folk remedy for different ailments such as sore throats, cramps, muscle aches, constipation arthritis, rheumatism, among others (Ali., et al. 2008). Some of the major isolated bioactive constituents of ginger include shogaol, 3-dihydroshogaol, paradols, dihydroparadols, gingerols, zingerone and volatile oils (Jolad., et al. 2004). Among the essential oils, major components include camphene, sabinene, $\alpha$-curcumin, zingiberene, $\alpha$-farnesene, $\beta$-sesquiphellandrene, neral, and geranial [1]. Ginger has demonstrated several pharmacological and therapeutic effects including analgesic (Ali., et al. 2008), antiinflammatory [2,3], anti-oxidant [4,5], anti-microbial [6], and anticancer properties [7]. 6-shogaol, an important bioactive constituent of ginger has been shown to improve the antioxidant defense mechanism through the induction of Nrf2 and HO-1 regulated by p38 MAPK and PI3k/Akt pathway [4]. Previous studies have found the use of ginger to have a protective effect against reproductive toxicities [8] as well as stimulate the male reproductive system [9].

Kiss1 gene encodes a family of neuropeptides known as kisspeptin [10]. Its protein product, kisspeptin, was originally called metastatin because of its role in the suppression of metastatic spread of human melanomas [11], but has since been shown to play an important role in the control of several reproductive activities (Wolfe and Hussain, 2018). The expression of the Kiss1 gene plays a central role in the regulation of the mammalian reproductive axis (Wolfe and Hussain 2018). KISS1 gene expression regulates the secretion of gonadotropin-releasing hormone ( $\mathrm{GnRH}$ ) at puberty, which triggers the release of LH and FSH leading to sexual maturation (Rhie., et al. 2013). KISS1 gene is highly expressed in the anteroventral periventricular (AVPV) nucleus and the arcuate nucleus of the hypothalamus (Tena-Sempere, 2013). While predominantly expressed in the brain, KISS1 gene expression has been demonstrated in the ovary (Hu., et al. 2018), testis (Tariq., et al. 2013), liver, pancreas, and fat cells (Dudek., et al. 2016). Mutation or alteration in the Kiss1/Kiss1R signaling pathway has been shown to induce pathology; loss of Kiss1 expression has been found in active cancer progression [11], while inhibitory mutation of the Kiss1R gene is associated with hypogonadotropic hypogonadism [10]. The direct effect of Kiss1/Kiss1R signaling on GnRH cells in addition to initiating puberty also regulates post-pubertal fertility (Leon., et al. 2016).
The crucial role of the Kiss1 gene in the regulation of different reproductive activities has created a need to identify compounds or factors that could potentially regulate or influence its expression in different body tissues, as this could form a new basis for assessing the reproductive benefit or toxicity of compounds. Moreover, previous studies have found the administration of ginger to not only stimulate the male reproductive system [9], and ameliorate reproductive toxicity [8], but also to influence the level of gene expression in different body tissues $[12,13]$. In this present study, we investigated the changes in expression levels of the Kiss1 gene in the blood and testis of Wistar rats, following the administration of methanolic extract of zingiber officinale (MEZO).

\section{Materials and Methods}

Study setting

This experimental study was carried out in the research laboratory of the Department of Anatomy, Faculty of Basic Medical Sciences, Nnamdi Azikiwe University, College of Health Science, Nnewi Campus, Anambra State, and lasted for about 3 months.

\section{Plant collection, identification, and extraction}

The aerial part of the plant was harvested from Nnewi, Anambra state. The botanical identification and authentication were carried out in the Department of Pharmacognosy and Traditional Medicine, College of Pharmacy, Nnamdi Azikiwe University, Agulu Campus, Anambra State, Nigeria with identification number PCG/474/A/024. The plant calyces were shade-dried and ground. $1000 \mathrm{~g}$ of powdered plant sample was used for methanolic extraction as described by Okafor and Ezejindu (2014). The filtrate (extract) was then stored in the refrigerator at $4^{\circ} \mathrm{C}$. The extract was made up to solution at varying doses per ml on each day of administration and given according to body weight and group treatment doses.

\section{Animal procurement, Care and Handling}

Fifteen (15) male Wistar rats were procured from the animal house of College of Health Sciences, Nnamdi Azikiwe University, Okofia Nnewi Campus and acclimatized for two (2) weeks (to exclude any intercurrent infection) under standard housing condition (ventilated room with 12/12-hour light/dark cycle at 24 $\pm 2^{\circ} \mathrm{C}$ ). The rats were fed ad libitum with water and standard rat chow throughout the experimental period. Animal health status was monitored throughout the experiment according to the federation of European Laboratory Animal Science Associations (FELA$\mathrm{SA}$ ) guidelines. 
Zingiber officinale (Ginger) Extract has No Effect on Kiss1 Gene Expression in the Testis and Blood but May Cause Inflammation-induced Morphological Sperm Disruptions in Wistar Rats

\section{Experimental design}

The rats with an average weight of $104 \mathrm{~g}$ were randomly divided into three (3) groups (A-C) $(n=5)$. Group A was given no treatment and served as the normal control group. Groups $\mathrm{B}$ and $\mathrm{C}$ received oral administration of $200 \mathrm{mg} / \mathrm{kg}$ and $400 \mathrm{mg} / \mathrm{kg}$ of MEZO respectively. The extract was administered once a day for 21 days and the animals were sacrificed at the end of the experiment.

\section{Animal sacrifice and sample collection}

The animals were fasted overnight on the last day of MEZO administration and anesthetized using chloroform. $2 \mathrm{~mL}$ of blood was collected from the animals by ocular puncture using capillary tubes into two different sample tubes. One was collected into a plain tube for hormonal assay, and the other into an RNA protector-containing plain tubes for Kiss 1 gene analysis. The animals were sacrificed after blood collection, and the testicular tissues were harvested, weighed, and divided into three parts. One part was fixed in a $10 \%$ formal saline for histological processing and analysis. The second part was homogenized and used for oxidative status analysis. The last part was stored in an RNA protector-containing plain tube before RNA isolation.

\section{Hormonal assay}

The blood was allowed to clot and centrifuged at 5,000 rpm for 10 minutes within one hour after collection. The serum was extracted and used for the hormonal assay. AccuBind enzyme-linked immunosorbent assay (ELISA) microwells for Follicle-stimulating hormone (FSH), Luteinizing hormone (LH), and Testosterone (TT) purchased from Calbiotech Inc. (catalog number: E5380s), Bioassay technology laboratory China (catalog number: E0182Ra), Bioassay technology laboratory (catalog number E0179Ra) respectively were used for the hormonal assay. All the hormonal analyses were carried out following the accompanying ELISA kit protocol for each parameter.

\section{Testicular oxidant status}

Superoxide Dismutase (SOD), Glutathione (GSH), and Catalase (CAT) levels were quantified in the testicular tissues to determine the oxidant status using the tissue homogenate derived from one part of the testis. The protocol used for this has been described in our previous studies (Okafor and Gbotolorun, 2018).

\section{Kiss1 RNA extraction}

Total RNA was extracted using the Zymo Research (ZR) wholeblood RNA MiniPrep according to ZR specification. A $600 \mu \mathrm{l}$ vol- ume red blood cell lysis buffers were added to $200 \mu$ l volume of ribonucleic acid-guard (RNAguard) stored whole blood sample in an RNase-free tube and mixed by inverting. The mixture was incubated for 5 minutes at $250^{\circ} \mathrm{C}$ and centrifuge at $\geq 12,000 \times \mathrm{g}$ for 1 minute. The supernatant was removed. A $600 \mu \mathrm{l}$ volume of blood RNA buffer was added to the cell pellet and mixed properly. The resultant mixture was transferred into the Zymo-Spin IIIC column in a collection tube and centrifuged at $\geq 12,000 \times \mathrm{g}$ for 2 minutes. The column was transferred into a new collection tube. A $400 \mu$ l volume of RNA pre-wash buffer was added to the column and centrifuged at $\geq 12,000 \times \mathrm{g}$ for 30 seconds. The column was transferred into an RNase free tube. $100 \mu \mathrm{l}$ RNA recovery buffer was added to the Zymo spin IIIC column and centrifuged at $\geq 12,000 \times \mathrm{g}$ for 30 seconds. A $100 \mu$ l volume ethanol (100\%) was added to the flow-through in the RNase free tube and mixed by pipetting. The mixture was transferred into the Zymo spin IC column in a collection tube and centrifuged at $\geq 12,000 \times \mathrm{g}$ for 30 seconds. A $400 \mu \mathrm{l}$ volume of the RNA prep buffer was added to the column and centrifuged at $\geq 12,000 \times$ $\mathrm{g}$ for 1 minute, the flow-through was discarded. An $800 \mu \mathrm{l}$ volume of the RNA wash buffer was added to the column and centrifuged at $\geq 12,000 \times \mathrm{g}$ for 1 minute, the flow-through was discarded. The wash step was repeated with $400 \mu$ volume of RNA wash buffer. The Zymo-spin IC column was centrifuged in an empty collection tube at $\geq 12,000 \times \mathrm{g}$ for 2 minutes. It was then transferred into an RNase free tube. Total RNA was eluted by added $80 \mu \mathrm{l}$ volume of DNase/RNase free water directly to the column matrix and centrifuged at $10,000 \times \mathrm{g}$ for 30 seconds. A $70 \mu \mathrm{l}$ volume of the Total RNA extracted was transferred into an RNA stable tube supplied by Biomatrica (catalog number 93221-001) for storage of Total RNA at room temperature while $10 \mu \mathrm{l}$ was used for quality control check on the total RNA extracted.

\section{RNA detection}

One gram of agarose powder was weighed and poured into 100 $\mathrm{ml}$ of Tris EDTA buffer in a Pyrex conical flask. It was heated using a microwave at $100^{\circ} \mathrm{C}$ for 5 minutes. It was allowed to cool to $56^{\circ} \mathrm{C}$ and $6 \mu$ l volume of ethidium bromide was added to $100 \mathrm{ml}$ of the gel mixture. The gel was poured into the electrophoresis chamber and allowed to solidify. A $3 \boldsymbol{\mu l}$ volume of loading dye was added to $7 \boldsymbol{\mu l}$ volume of the Total RNA from each sample, the molecular marker was loaded in the first lane, followed by the samples. Electrophoresis was performed at 90 volts for 30 minutes. The gel was removed and viewed on the UV transilluminator; the picture of the gel was taken. 
Zingiber officinale (Ginger) Extract has No Effect on Kiss1 Gene Expression in the Testis and Blood but May Cause Inflammation-induced Morphological Sperm Disruptions in Wistar Rats

Reverse transcriptase-polymerase chain reaction (RT-PCR)

The extracted total RNA was retro-transcribed and amplified using One Taq one-Step RT-PCR kit (catalog number NEB E5315S) by New England BioLabs incorporation according to the manufacturer's specification. Selected primers were used to target lymphocyte genes using MJ research Peltier thermal cycler polymerase chain reaction machine. The PCR was performed in a $50 \mu \mathrm{l}$ volume reaction mixture containing $25 \mu \mathrm{l}$ volume of one Taq one-step reaction master mix ( $2 x), 2 \mu$ l volume of One Taq one-step enzyme mix (2x), $2 \mu$ l volume of each gene-specific forward primer $(10 \mu \mathrm{M}), 2$ $\mu \mathrm{l}$ volume of each gene-specific reverse primer $(10 \mu \mathrm{M}), 9 \mu \mathrm{l}$ volume of nuclease-free water and $10 \mu \mathrm{l}$ volume of the RNA template was added. Negative control samples for the RT-PCR consisted of a mixture to which all reagents added except RNA. The PCR was started immediately as follows: Reverse transcriptase at $48^{\circ} \mathrm{C}$ for 30 seconds, initial denaturation at $94^{\circ} \mathrm{C}$ for 1 minute, denaturation at $94^{\circ} \mathrm{C}$ for 15 seconds, annealing at $\mathrm{Tm}^{\circ} \mathrm{C}-5$ (the lowest melting temperature of each set of KISS1 gene) for 30 seconds, extension at $68^{\circ} \mathrm{C}$ for 1 minute, denaturation step for 39 cycles, final extension at $68^{\circ} \mathrm{C}$ for 5 minutes and final holding at $4^{\circ} \mathrm{C}$, forever. The Kiss 1 gene nucleotide sequence $\left(5^{\prime}-3^{\prime}\right)$ for the primers are as follows: forward primer - CTACGACTCCTTGTTGCTTTG, and reverse primer - TGATCTTCACTGTAGTTGGTGG.

\section{Electrophoresis}

$5 \mu \mathrm{l}$ of the amplified PCR products and DNA ladder were analyzed on $1 \%$ agarose gel containing ethidium bromide in $1 \mathrm{X}$ Tris EDTA buffer One percent agarose gel was prepared by dissolving $1.0 \mathrm{~g}$ of LE agarose powder in $100 \mathrm{ml}$ volume of Tris Borate EDTA Buffer. The mixture was then heated in a microwave at $1000 \mathrm{C}$ for 5 minutes and allowed to cool to $56^{\circ} \mathrm{C}$ and $6 \mu$ volume of ethidium bromide was added to it. The agarose gel was poured into the electrophoresis chambers with gel comb and allowed to solidify. Electrophoresis was performed at 90 volts for 30 minutes with the Edvotek tetra source electrophoresis machine, Bethesda, USA. After electrophoresis Kiss1 gene was visualized with the Wealtec Dolphin-Doc UV transilluminator and photographed.

\section{Kiss1 gene expression}

ImageJ 1.53a software was used to calculate the absolute intensity of expression from the generated gel images across all the experimental groups in both the blood and testis. ImageJ generates the absolute intensity (derived by mean value multiplied by the pixel value or percent for each band) of each band. The absolute intensity is an integrated measure of the intensity and size of the band. The relative intensity was calculated by dividing the absolute intensity of each sample band by the absolute intensity of the standard.

\section{Tissue processing}

The testicular tissue samples were trimmed down to a size of about $3 \mathrm{~mm} \times 3 \mathrm{~mm}$ thick for an easy study of sections under the light microscope and fixed in $10 \%$ formalin. After fixation, dehydration of the fixed tissues was done in ascending grades of alcohol $50 \%, 70 \%, 95 \%$, and $100 \%$, and cleared in xylene. Staining was done with hematoxylin and eosin (H\&E) and mounted using DPX, after which, the sections were viewed under the light microscope. Photomicrographs of these sections were obtained using the Leica DM 750 digital light microscope photomicrography computer software.

\section{Statistical analysis}

The data were analyzed using IBM statistical package for social science (SPSS) for Windows, version 23 (IBM Corporation, Armonk, New York, USA). One-way analysis of variance (ANOVA), post hoc LSD, student's t-test, and Pearson's correlation analysis was used to test for significance in changes seen in the variables across groups. Tables and figures were used for the representation of data, and values were considered significant at $\mathrm{p}<0.05$.

\section{Ethical statement}

This study was approved by the Research Ethics Committee of Anatomy Department, Faculty of Basic Medical Sciences, Nnamdi Azikiwe University, Nnewi Campus. The experimental procedures of this study complied with ARRIVE guidelines, National Institutes of Health (NIH) guidelines, and National Health Research ethics committee of Nigeria (NHREC) guidelines for the care and use of laboratory animals. No informed consent was required for this study.

\section{Results}

\section{The effect of MEZO on body weight}

There was a significant increase in the body weight of animals in group B after administration of MEZO ( $p=0.001)$. Groups A and $C$ showed no significant difference in body weight when the pre and post-administration body weights were compared $(p=0.356$, 0.087) (Table 1). 
Zingiber officinale (Ginger) Extract has No Effect on Kiss1 Gene Expression in the Testis and Blood but May Cause Inflammation-induced Morphological Sperm Disruptions in Wistar Rats

\begin{tabular}{|l|c|c|c|}
\hline \multirow{2}{*}{ Groups } & & $\begin{array}{c}\text { Body weight } \\
\text { Mean } \pm \text { SEM (g) }\end{array}$ & \multirow{2}{*}{ p-value } \\
\hline \multirow{2}{*}{ A } & Pre-administration & $100.00 \pm 15.81$ & \multirow{2}{*}{0.356} \\
\cline { 2 - 3 } & Post-administration & $116.00 \pm 20.74$ & \\
\hline \multirow{2}{*}{ B } & Pre-administration & $104.00 \pm 5.48$ & \multirow{2}{*}{$0.001^{*}$} \\
\cline { 2 - 3 } & Post-administration & $164.00 \pm 15.17$ & \\
\hline \multirow{2}{*}{ C } & Pre-administration & $107.50 \pm 23.63$ & \multirow{2}{*}{0.087} \\
\cline { 2 - 3 } & Post-administration & $170.00 \pm 34.64$ & \\
\hline
\end{tabular}

Table 1: The effect of the MEZO on the bodyweight of male Wistar rats.

Data were analyzed using the Students' dependent t-test. Values were expressed as mean \pm SEM (Standard error of mean) and were considered significant at $* \mathrm{p}<0.05$. Group A served as control and received only distilled water, group B received $200 \mathrm{mg} / \mathrm{kg}$ of MEZO and group $\mathrm{C}$ received $400 \mathrm{mg} / \mathrm{kg}$ of MEZO, MEZO means methanolic extract of Zingiber officinale.

\section{The effect of MEZO on relative testicular weight}

There was a significant increase in the relative testicular weight in group $C$ when compared to the control group $(p=0.007)$ (Table 2).

\begin{tabular}{|l|c|c|}
\hline Groups & Mean \pm SEM (g) & p-value \\
\hline A & $0.900 \pm 0.357$ & - \\
\hline B & $1.087 \pm 0.933$ & 0.153 \\
\hline C & $1.287 \pm 0.571$ & $0.007^{*}$ \\
\hline
\end{tabular}

Table 2: The effect of MEZO on the relative testicular weight of Wistar rat.

Data were analyzed using one-way ANOVA, followed by post-hoc analysis using Fischer's LSD. Values were expressed as mean \pm SEM (Standard error of mean) and were considered significant at ${ }^{*} p<$ 0.05. Group A served as control and received only distilled water, group B received $200 \mathrm{mg} / \mathrm{kg}$ of $\mathrm{MEZO}$ and group $\mathrm{C}$ received 400 $\mathrm{mg} / \mathrm{kg}$ of MEZO, MEZO means methanolic extract of Zingiber officinale.

The effect of MEZO on reproductive hormones

There was no significant difference in the LH, FSH and TT levels across all the experimental groups ( $<<0.05)$ (Table 3).

Epididymal sperm assessment following MEZO administration

Table 2 shows the sperm count, motility, and morphology of the Wistar Rat following the administration of MEPO. The sperm count and sperm motility were not significantly different across treatment groups when compared to the control group $(\mathrm{p}<0.05)$. There was a significant decrease in the sperm morphology observed in group $C$ when compared to the control $(p=0.007)$ (Table 4).

\begin{tabular}{|c|c|c|c|}
\hline Hormones & Groups & MEAN \pm SEM & $p$-value \\
\hline \multirow{3}{*}{$\mathrm{LH}(\mathrm{mIU} / \mathrm{ml})$} & A & $4.83 \pm 0.38$ & \multirow{3}{*}{0.697} \\
\hline & B & $5.98 \pm 2.88$ & \\
\hline & $\mathrm{C}$ & $3.47 \pm 2.64$ & \\
\hline \multirow{3}{*}{$\mathrm{FSH}(\mathrm{mIU} / \mathrm{ml})$} & A & $8.37 \pm 4.25$ & \multirow{3}{*}{0.552} \\
\hline & B & $6.00 \pm 2.28$ & \\
\hline & $\mathrm{C}$ & $6.87 \pm 0.42$ & \\
\hline \multirow{3}{*}{ TT (ng/ml) } & A & $0.48 \pm 0.26$ & \multirow{3}{*}{0.792} \\
\hline & B & $0.66 \pm 0.63$ & \\
\hline & $\mathrm{C}$ & $0.76 \pm 0.56$ & \\
\hline
\end{tabular}

Table 3: The effect of MEZO on the LH, FSH and TT levels of male Wistar rat.

Data were analyzed using one-way ANOVA. Values were expressed as mean \pm SEM (Standard error of mean) and were considered significant at $* \mathrm{p}<0.05$. Group A served as control and received only distilled water, group B received $200 \mathrm{mg} / \mathrm{kg}$ of MEZO and group C received $400 \mathrm{mg} / \mathrm{kg}$ of MEZO, MEZO means methanolic extract of Zingiber officinale.

\begin{tabular}{|l|c|c|c|c|}
\hline & $\begin{array}{c}\text { Group A } \\
\text { (Mean } \pm \\
\text { SEM) }\end{array}$ & $\begin{array}{c}\text { Group B } \\
\text { (Mean } \pm \\
\text { SEM) }\end{array}$ & $\begin{array}{c}\text { Group C } \\
\text { (Mean } \pm \\
\text { SEM) }\end{array}$ & $\begin{array}{c}\boldsymbol{p} \text { - } \\
\text { value }\end{array}$ \\
\hline Sperm Motil- & $60.00 \pm$ & $37.50 \pm$ & $65.00 \pm$ & 0.159 \\
ity (\%) & 10.00 & 10.31 & 7.64 & \\
\hline Sperm Count & $15.88 \pm$ & $7.33 \pm$ & $19.77 \pm$ & 0.337 \\
$\left(x 10^{6}\right)$ & 5.90 & 3.09 & 6.71 & \\
\hline Sperm Mor- & $85.00 \pm$ & $83.75 \pm$ & $80.00 \pm$ & -0.351 \\
phology (\%) & 0.00 & 1.25 & 0.00 & \\
& & & & $0.007 *$ \\
\hline
\end{tabular}

Table 4: The effect of MEZO on the sperm count, motility and morphology of Wistar rats.

Data were analyzed using one-way ANOVA followed by post-hoc Fisher's LSD multiple comparisons. Values are significant at $\mathrm{p}<$ 0.05 . *means Significant at $\mathrm{p}<0.05$. Group A served as control and received only distilled water, group $B$ received $400 \mathrm{mg} / \mathrm{kg}$ of MEPO and group $\mathrm{C}$ received $800 \mathrm{mg} / \mathrm{kg}$ of MEPO, MEPO means methanolic extract of Portulaca oleracea, SEM means standard error of the mean. 
Zingiber officinale (Ginger) Extract has No Effect on Kiss1 Gene Expression in the Testis and Blood but May Cause Inflammation-induced Morphological Sperm Disruptions in Wistar Rats

The effect of MEZO on the testicular antioxidant levels

No significant changes were observed in the testicular antioxidant levels (SOD, GSH and CAT) when the treatment groups were compared to the control $(\mathrm{p}<0.05)$ (Table 5).

\begin{tabular}{|c|c|c|c|}
\hline Antioxidants & Groups & Mean \pm SEM & p-value \\
\hline \multirow{3}{*}{$\begin{array}{l}\mathrm{SOD}(\mu \mathrm{mol} / \mathrm{ml} / \mathrm{min} / \mathrm{mg} \\
\text { pro). }\end{array}$} & A & $18.67 \pm 0.68$ & \multirow{3}{*}{0.872} \\
\hline & $\mathrm{B}$ & $18.58 \pm 0.15$ & \\
\hline & $\mathrm{C}$ & $18.00 \pm 2.40$ & \\
\hline \multirow{3}{*}{ GSH ( $\mu \mathrm{mol} / \mathrm{ml} / \mathrm{mg}$ pro $)$} & $\mathrm{A}$ & $\begin{array}{c}23.36 \pm \\
20.07\end{array}$ & \multirow{3}{*}{0.249} \\
\hline & $\mathrm{B}$ & $\begin{array}{c}36.34 \pm \\
11.44\end{array}$ & \\
\hline & $\mathrm{C}$ & $13.51 \pm 9.29$ & \\
\hline \multirow{3}{*}{$\begin{array}{l}\text { CAT }(\mu \mathrm{mol} / \mathrm{ml} / \mathrm{min} / \mathrm{mg} \\
\text { pro) }\end{array}$} & A & $94.13 \pm 7.69$ & \multirow{3}{*}{0.405} \\
\hline & $\mathrm{B}$ & $87.14 \pm 2.67$ & \\
\hline & $\mathrm{C}$ & $87.56 \pm 5.94$ & \\
\hline
\end{tabular}

Table 5: The effect of MEZO on SOD, GSH and CAT level of male wistar rats.

Data were analyzed using one-way ANOVA. Values were expressed as mean \pm SEM (Standard error of mean) and were considered significant at $* \mathrm{p}<0.05$. Group A served as control and received only distilled water, group B received $200 \mathrm{mg} / \mathrm{kg}$ of MEZO and group C received $400 \mathrm{mg} / \mathrm{kg}$ of MEZO, MEZO means methanolic extract of Zingiber officinale.

\section{Histopathological findings}

Figure 1 shows the photomicrograph of the testis of all experimental animals. Plate 1 represents a section of rat testis administered only distilled water for 21 days. The histological section showed a normal tissue with no sign of abnormality. Plate 2 represents the histological section of rat testis administered $200 \mathrm{mg} / \mathrm{kg}$ of MEZO for 21 days. The section showed a normal tubule lined by spermatogenic series cells with luminal spermatozoa. Plate 3 represents the photomicrograph of rat testis administered $400 \mathrm{mg} / \mathrm{kg}$ of MEZO for 21 days. The tissue shows signs of vascular congestion, with aggregates of inflammatory red cells visible in the vessels. The spermatogenic series cells and interstitial cells can be seen in the section. Staining for all sections was done using hematoxylin and eosin, and photomicrography was taken at x200.

The Effect of MEZO on Kiss1 gene expression in the blood and testis

RT-PCR band images (Figure 2A and 2B) show the detection of the Kiss 1 gene in both the blood and the testis of Wistar rats in all the test groups, at different intensities. Figure 2 represents the PCR amplicon bands of KISS1 gene expression in the blood (A) and the testis (B). There is no significant difference in the KISS1 gene expression levels in the blood ( $p=0.247)$ and the testis $(p=0.255)$ across all treatment groups. There is also no significant difference between the relative expression intensity observed in the blood compared to the testis in each experimental group except in group $B$ where the expression in the testis is significantly higher than that of the blood (A = CI: $-2.37-1.91, \mathrm{p}=0.68$; $\mathrm{B}=\mathrm{CI}:-1.39--0.05, \mathrm{p}=$ 0.045; C = CI:-0.07 - 1.02, $\mathrm{p}=0.065$ ) (Figure 2C).

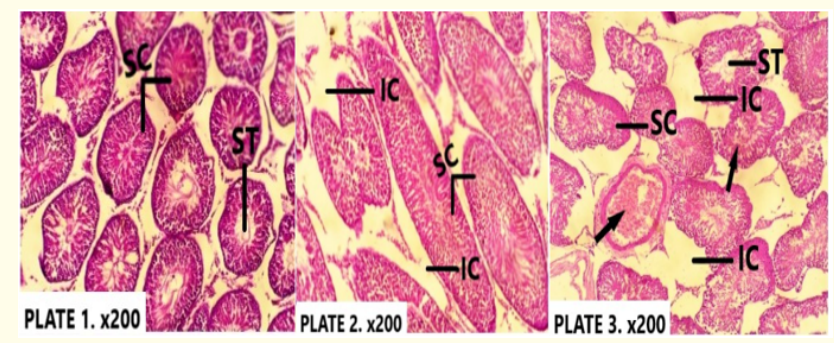

Figure 1: (Plate 1-3): Plate 1: Histologic section of the testis of rat administered only distilled water for 21 days. (H \& E x 200); Plate 2: Histologic section of the testis of rat administered $200 \mathrm{mg} / \mathrm{kg}$ MEZO for 21 days. (H \& E x 200); Plate 3: Histologic section of the testis of rat administered $400 \mathrm{mg} / \mathrm{kg}$ MEZO for 21 days (H \& E x 200). ST: Seminiferous Tubule, SC: Spermatogenic Series Cell, IC: Interstitial Cells, Arrows: vascular congestion around spermatogenic series cells.
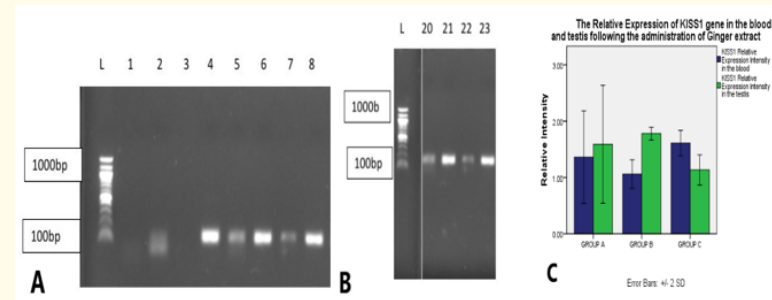

Figure 2: (A-C): A shows an RT-PCR image of Kiss1 gene expression on the blood of an adult male Wistar rat analyzed on a 1.0 $\%$ agarose gel electrophoresis stained with ethidium bromide. Group A (bands 5 and 6), group B (band 7), group C (band 8). L is a 100bp-1000bp DNA ladder (molecular marker). Samples 2, 4, 5, 6, 7, 8 represent positive bands for the expressed Kiss1 genes at $100 \mathrm{bp}$. B shows an RT-PCR image of Kiss1 gene expression on the testis of an adult male Wistar rat analyzed on a $1.0 \%$ agarose gel electrophoresis stained with ethidium bromide. Group A (band 20 and 23), group B (band 21), group C (band 22). L is a 100bp1000bp DNA ladder (molecular marker). Samples 20, 21, 22, and 23 show positive bands for the expressed Kiss1 genes at 100bp. C shows the Relative Intensity of Kiss 1 gene expression in the blood and the testis in each experimental group. 
Zingiber officinale (Ginger) Extract has No Effect on Kiss1 Gene Expression in the Testis and Blood but May Cause Inflammation-induced Morphological Sperm Disruptions in Wistar Rats

Correlation between Kiss1 gene expression and reproductive Hormonal levels

There is no significant correlation between the relative intensity of Kiss 1 expression intensity in the testis and the reproduc- tive hormones ( $p>0.05)$. There is a significant negative correlation between the sperm count and the relative intensity of Kiss1 gene expression in the blood $(\mathrm{p}=0.20)$ (Table 6).

\begin{tabular}{|c|c|c|c|c|c|c|c|}
\hline \multicolumn{2}{|c|}{} & LH & FSH & TT & $\begin{array}{c}\text { Sperm } \\
\text { motility }\end{array}$ & $\begin{array}{c}\text { Sperm } \\
\text { count }\end{array}$ & $\begin{array}{c}\text { Sperm mor- } \\
\text { phology }\end{array}$ \\
\hline \multirow{2}{*}{ RIB } & Pearson Correlation & -.843 & -.801 & .824 & -.934 & $-.882^{*}$ &.${ }^{\mathrm{b}}$ \\
\cline { 2 - 8 } & Sig. (2-tailed) & .157 & .199 & .176 & .066 & .020 & .000 \\
\hline \multirow{2}{*}{ RIT } & Pearson Correlation & .254 & .443 & -.189 & .748 & .459 &.${ }^{\mathrm{b}}$ \\
\cline { 2 - 8 } & Sig. (2-tailed) & .746 & .557 & .811 & .252 & .360 & .000 \\
\hline
\end{tabular}

Table 6: Correlation between the relative intensity of Kiss1 gene expression, hormonal levels and sperm indices.

RIB: Relative Expression Intensity in the Blood; RIT: Relative Expression Intensity in the Testis; LH: Luteinizing Hormone; FSH: Folliclestimulating Hormone; TT: Testosterone; ${ }^{*}$ Correlation is significant at the 0.05 level (2-tailed). ${ }^{b}$ Cannot be computed because at least one of the variables is constant.

\section{Discussion}

Existing literature on Zingiber officinale has shown the plant to be an important medicinal plant with a diverse nutritional and pharmacological spectrum [14]. In this present study, we investigated the effects of Zingiber officinale on Kiss1 gene expression levels in the blood and testis. We also assessed the changes that occurred in the oxidative status, testicular weight, reproductive hormones, sperm parameters, and testicular histology.

We observed a significant increase $(p=0.001)$ in the bodyweight of animals treated with $200 \mathrm{mg} / \mathrm{kg}$ MEZO when the pre and postadministration body weight were compared while those treated with $400 \mathrm{mg} / \mathrm{kg}$ MEZO showed no significant change in their body weight ( $p=0.087$ ) after MEZO administration (Table 1).

Changes in the relative weight of an organ is an important marker of tissue toxicity [15]. As observed in this study (Table 2), MEZO did not cause any significant change in the relative testicular weight of the treated animals when compared to the control $(\mathrm{p}>$ 0.05).

MEZO did not cause any effect on the expression of the Kiss1 gene in the testis and blood, as no significant difference was observed in the relative intensity of Kiss1 gene expression in both the testis ( $p=0.255)$ and the blood ( $p=0.247)$ across all MEZO-treated groups when compared to the control (Figure 2). Changes in the expression of the testicular Kiss1 gene have been shown to have an impact on the steroidogenic activities of Leydig cells [16]. The interruption of testicular Kiss1 gene expression is associated with a decreased testosterone level [17]. The relatively constant level of Kiss1 gene expression could explain why no changes were observed in the hormonal parameters. As observed (Table 3), treatment with MEZO did not cause any significant change in the levels of serum LH, FSH, and TT. This finding agrees with the findings of Afzali and Ghalehkandi [18] which reported no significant change in $\mathrm{LH}, \mathrm{FSH}$, and testosterone levels following treatment with 100, 200 , and $300 \mathrm{mg} / \mathrm{kg}$ of aqueous ginger extract.

Similarly, sperm motility, sperm count, and sperm morphology showed no significant difference in all experimental groups $(\mathrm{p}<$ 0.05), except for group C (administered with 400mg/kg of MEZO) where a significant decrease in sperm morphology was observed, when compared to the control $(p=0.007)$ (Table 4). Histological findings showed some vascular congestion, with aggregates of inflammatory red cells present among the cells lining the seminiferous tubule in group $\mathrm{C}$. The observed sperm morphological disruptions and presence of inflammatory cells are quite unexpected outcomes and could be due to functional abnormalities associated with the inflammatory response of ginger [12]. Interestingly, MEZO did not induce oxidative stress damage in the testicular tissue; SOD, GSH, and CAT showed no significant alteration across treated groups when compared to the control (Table 5). Although some studies on the reproductive effect of ginger have also reported mild interstitial vascular congestion in the testis [19], the mechanism underlying this effect remains largely unknown. Furthermore, correlation studies found a significant negative correlation between the sperm count and the relative intensity of Kiss 1 gene expression 
Zingiber officinale (Ginger) Extract has No Effect on Kiss1 Gene Expression in the Testis and Blood but May Cause Inflammation-induced Morphological Sperm Disruptions in Wistar Rats

in the blood ( $\mathrm{r}=-.882, \mathrm{p}=0.020$ ) (Table 6). This indicates a potential prediction of sperm count parameters using the Kiss1 gene expression in the blood. No significant correlation was however found between the relative intensity of Kiss1 expression in the testis and the reproductive hormones $(p>0.05)$ (Table 6).

According to our findings, Kiss1 gene expression appeared to be more pronounced in the testis than in the blood. As observed (Figure 2), Kiss1 gene expression following administration of 200 $\mathrm{mg} / \mathrm{kg}$ MEZO showed a significantly higher relative intensity in the testis, when compared to its expression in the blood (CI: -1.39 $(-0.05), p=0.045)$. Also, different doses of MEZO observed showed no effect on the expression levels of the Kiss1 gene in the blood and testis.

In summary, $400 \mathrm{mg} / \mathrm{kg}$ ginger caused a significant decrease in the sperm morphology; and also induced mild vascular congestion around the tubular cells of the testis (Figure 1). The mechanism behind the observed decrease in sperm morphology and mild vascular congestion remains unclear. Sperm count, sperm motility, oxidative stress status, and hormonal parameters all showed no significant changes following the administration of different doses of MEZO.

\section{Conclusion}

MEZO has no significant effect on the level of KISS1 gene expression in the testis and blood of Wistar rats. However, at a higher dose, MEZO demonstrated signs of reproductive toxicity as it caused sperm morphological disruptions and testicular inflammatory response. MEZO did not cause any alteration in the sperm count, sperm motility, hormonal parameters, and testicular oxidative stress markers. We recommend further chronic studies on the reproductive effect of MEZO, to delineate the mechanism of action, as well as the dose-effect relationship in the reported findings.

\section{Acknowledgments}

We want to thank Dr. Alfred Ehiaghe for his assistance with the gene expression laboratory work.

\section{Conflict of Interest}

The authors have no conflict of interest to declare.

\section{Bibliography}

1. Yeh H yu., et al. "Bioactive components analysis of two various gingers (Zingiber officinale Roscoe) and antioxidant effect of ginger extracts". LWT - Food Science and Technology 55.1 (2014): 329-334.
2. Khan A M., et al. "Zingiber officinale ameliorates allergic asthma via suppression of Th2-mediated immune response". Pharmaceutical Biology (2015).

3. Lantz R C., et al. "The effect of extracts from ginger rhizome on inflammatory mediator production. Phytomedicine (2007).

4. Bak M J., et al. "6-shogaol-rich extract from ginger up-regulates the antioxidant defense systems in cells and mice". Molecules 17.7 (2012): 8037-8055.

5. Hosseinzadeh A., et al. "Protective Effect of Ginger (Zingiber officinale Roscoe) Extract against Oxidative Stress and Mitochondrial Apoptosis Induced by Interleukin-1 $\beta$ in Cultured Chondrocytes". Cells Tissues Organs 204 (2017): 241-250.

6. Islam K., et al. "Antimicrobal Activity of Ginger (Zingiber Officinale) Extracts Against Food-Borne Pathogenic Bacteria". International Journal of Science, Environment and Technology (2014).

7. Rhode J., et al. "Ginger inhibits cell growth and modulates angiogenic factors in ovarian cancer cells". BMC Complementary and Alternative Medicine (2007).

8. Oda S S and Waheeb R S. "Ginger attenuated DI (N-butyl) phthalate-induced reproductive toxicity in pubertal male rabbits". World Rabbit Science (2018).

9. Bordbar H., et al. "Stereological study of the effect of ginger's alcoholic extract on the testis in busulphan-induced infertility in rats". International Journal of Reproductive BioMedicine 11.6 (2013): 467-472.

10. Silveira L G., et al. "Mutations of the KISS1 gene in disorders of puberty. Journal of Clinical Endocrinology and Metabolism 95.1 (2010): 2276-2280.

11. Shirasaki F., et al. "Loss of expression of the metastasis suppressor gene Kiss1 during melanoma progression and its association with LOH of chromosome 6q16.3-q23". Cancer Research (2001).

12. Ahmadifar E., et al. "Can dietary ginger (Zingiber officinale)alter biochemical and immunological parameters and gene expression related to growth, immunity and antioxidant system in zebrafish (Daniorerio)?" Aquaculture 507 (2019): 341-348.

13. Elkady A I., et al. "Differential control of growth, apoptotic activity, and gene expression in human breast cancer cells by extracts derived from medicinal herbs Zingiber officinale". Journal of Biomedicine and Biotechnology (2012). 
14. Ravindran P N and Babu K N. "Ginger: The genus Zingiber". In Ginger: The Genus Zingiber (2016).

15. Sellers R S., et al. "Society of Toxicologic Pathology position paper: organ weight recommendations for toxicology studies". Toxicologic Pathology (2007).

16. Chianese R., et al. "Kisspeptins, Estrogens and Male Fertility". Current Medicinal Chemistry (2016).

17. Aytürk N., et al. "The effect of kisspeptin on spermatogenesis and apoptosis in rats. Turkish Journal of Medical Sciences 47.1 (2017): 334-342.

18. Afzali A and Ghalehkandi JG. "Effect of ginger, Zingiber officinale on sex hormones and certain biochemical parameters of male Wistar rats". Biochemical Communication 11.1 (2018): 181-186.

19. Ataman JE and Ojukwu F. "Protective Effects of Aqueous Extract of Ginger on Castor-oil - Induced Testicular Damage in Wistar Rats". 14.4 (2014): 199-205.

\section{Assets from publication with us}

- Prompt Acknowledgement after receiving the article

- Thorough Double blinded peer review

- Rapid Publication

- Issue of Publication Certificate

- High visibility of your Published work

Website: www.actascientific.com/

Submit Article: www.actascientific.com/submission.php

Email us: editor@actascientific.com

Contact us: +919182824667 